\title{
クラスタービームと固体の相互作用の 計算機シミュレーション
}

\author{
中川幸子 \\ 岡山理科大学理学研究科 函700-0005 岡山県岡山市理大町 1-1
}

(2010 年 8 月 2 日受理)

\section{A Modeling for the Interaction between a Cluster Beam and Material}

\author{
Sachiko T. NAKAgawa \\ Graduate School of Science, Okayama University of Science \\ 1-1 Ridai-cho, Okayama 700-0005
}

(Received August 2, 2010)

\begin{abstract}
The characteristics of a cluster beam interaction with a solid target are reviewed from the viewpoint of computer simulation. The similarity and dissimilarity of irradiation effects between single and cluster ion beams are mentioned for small clusters. The scaling of the excitation process based on the concept of the stopping force fails for the case of cluster impacts because of the size effect. In the case of a huge cluster with a very low velocity as low as the sound velocity, such a scaling rule is not significant. The Clusterelectric effect is important, thus a new type of algorithm of the "coarsegrained quantum molecular dynamics" that should prove the observed Clusterelectric effect.
\end{abstract}

KEYWORDS : cluster, ion-surface interaction, computer simulation

1.はじめに：単原子ビームと物質の相互作用 *比較的高いエネルギーの単原子ビームに よる物質の励起過程は速度（エネルギー） でスケールできる*

入射イオンが引き起こす物質の変化には，エネルギー 付与の励起過程 ${ }^{1)}$ とエネルギーの再配分である緩和（応 答）過程との二段階がある ${ }^{2}$ 。固体中に留まらないイオ ンは後方に反跳, あるいは前方に透過するが, 残りは物 質中で緩和過程に関わる。物質に付与された励起エネル ギーは輻射か非輻射過程かによって緩和する。

励起過程の記述には, 単原子イオンから見た単位長当 たりのエネルギー損失を阻止能 $(\mathrm{d} E / \mathrm{dx})$ と定義した一 般性の高い LSS (Lindhard-Scharff-Schiott) 理論3)があ る。LSS 理論は, 『様々な衝突系（入射イオン＋標的原 子）で, 電子的阻止能 $(\mathrm{d} E / \mathrm{dx})_{\mathrm{e}}$ には速度スケーリング

E-mail : stnak@dap.ous.ac.jp
則, 核的阻止能 $(\mathrm{d} E / \mathrm{dx})_{\mathrm{n}}$ にはエネルギースケーリング 則が成立し, 二つの阻止能に分離して原子衝突を解析で きる』とする。クラスターイオンと物質の相互作用は, 当初, 等価速度（=構成原子あたりの入射エネルギー） で分類する方針があったので，本稿でも少なくとも少数 クラスターに関しては, 速度スケーリング則を準用する。 励起過程の大要が整理された LSS 理論の前提条件は,

(1) 単価数の単原子イオン $\left(\mathrm{Z}_{1}\right)+$ 単原子物質 $\left(\mathrm{Z}_{2}\right)$,

(2) 2 体衝突近似,

(3)二つの阻止能の分離，にある。

ここで提示された阻止能表式が，緩和過程の記述に必 要な熱力学的㧍よび弾性的パラメー夕を含まないことは 注目しておく必要がある。この前提に立った一般性の高 い計算機シミュレーションコードには $\mathrm{SRIM}^{4)}$ があり, 物質中に注入された入射イオンの飛程等の一般的な試計 算には実用的である。

三つの前提のうち，1に適しない例はクラスターイオ ンである。単原子イオンの場合と違い, 構造を持つ入射 
イオン自体が変形・解離・化合する相互作用の場を持ち 込む。(2に適しない例は，入射エネルギーによらず必然 的にクラスターイオンが行う, 物質との多重衝突であ る。また電子的阻止断面積が示す $Z_{1}$ と $Z_{2}$ に関する非対 称性 ${ }^{5)}$ の事実がある。この非対称性は固体の凝集方式の 違いを反映し，一方の原子が「長距離相互作用によって 固体を形成する特性」を反映している。(3)に適しない例 は，低エネルギークラスタービームによるエキシトン生 成につづく発光過程 ${ }^{6}$ にも見られ，低エネルギー領域に はLSS 理論の予測とは全く違った電子的過程の取り扱 いが必要である。

比較的高エネルギーの場合に有用であった LSS 理論 の基本骨格は尊重しつつも, クラスターイオンに対して 現実の解析で有用なのは，個別にカスタマイズした計算 機シミュレーションコードである。1960 年に Gibson $ら^{7)}$ が始めた分子動力学シミュレーション（Molecular Dynamics, MD）では, 経験的原子間ポテンシャル ${ }^{8}$ を使 って多重衝突のポテンシャル場を構成し，その勾配から 粒子系の力場を決めて, 粒子系の連立運動方程式を解く。

この運動方程式に摩擦項として $(\mathrm{d} E / \mathrm{dx})$ e を導入する と, MD が二つの阻止能を含むようにカスタマイズでき る。1989 年にCaro と Victoria ${ }^{9)}$ が提唱した LSS 理論の 一様電子ガスモデルの $(\mathrm{d} E / \mathrm{dx}) \mathrm{e}$ を導入する方法でのエ ネルギー下限は，実質的には $5^{10)}-10 \mathrm{eV}^{11)}$ で，これはス パッタリングにとっては重要なエネルギー範囲である。 しかし低速粒子に関しては, 密度汎関数法に基づいた局 所電子モデルの $(\mathrm{d} E / \mathrm{dx})_{\mathrm{e}}$ の方が一様電子ガスモデルよ り有意であり，それを MD に組み入れることは可能で ある ${ }^{12)}$ 。

実験で観測される一つの現象は, 時空（エネルギー, 空間座標，展開時間）の一枚の断面図である。一つの計 算プログラム（コード）は一つの物理モデルに従い，適 用できる時空に有限の幅があるので，その幅の範囲内 で, 注目する現象の変化を調べられる。しかし現象の全 体を見るには一つの物理モデルでは足りず，複数の物理 モデルを階層接続する。この試みはクラスター衝撃の場 合も同様で, 後に 3.2 で詳述するように, 1 秒くらいに まで時間を延長するキネテイックモンテカルロ（Kinetic Monte-Carlo, KMC) ${ }^{13}$ や, $1 \mathrm{meV}$ くらいにまでエネルギ 一精度を上げられる第一原理分子動力学 (ab initio Molecular Dynamics, $\mathrm{QMD}^{14)}$ ) などが, 古典的 MD の接続パ ートナーとなれる。
2. 少数クラスタービーム注 と物質の相互作用 *少数粒子系のクラスターの照射効果は, 速度（エネルギー）とサイズ効果が不分離 でスケールが難しい*

1956 年に Becker ら ${ }^{15}$ が初めて分子 $\left(\mathrm{H}_{2}, \mathrm{~N}_{2}\right)$ ビーム を用いるようになって，単原子ビームとの間の違いが指 摘され始めた。

照射が原因のある現象のイールド $(Y)$ について, $n$ 個の原子から成るクラスタービーム $\left(\mathrm{X}_{\mathrm{n}}{ }^{+}\right)$と単原子ビ 一ム $\left(\mathrm{X}^{+}\right)$による $Y$ の比 $R_{\mathrm{n}}=Y\left(\mathrm{X}_{\mathrm{n}}{ }^{+}\right) / n / Y\left(\mathrm{X}^{+}\right)$を指標 に選び， $R_{\mathrm{n}}$ が 1 より大きく異なるときに, クラスター 効果があるとした。入射エネルギー $\left(E_{\mathrm{c}}\right)$ のクラスター 効果 $R_{\mathrm{n}}$ の議論は, 一原子あたりの個別エネルギー $\left(E_{0}=E_{\mathrm{C}} / n\right)$ すなわち等価速度を共通軸に載せて始まっ た。ところが速度を揃えてもサイズ依存性が残ることが 明らかになった。また必ずしもクラスター固有と言えな いことが計算によって実証された現象もある。そこで, クラスター効果について実験で確認されている事害と, 理論や計算機シミュレーションで確認されてきた結果を 整理する。

\section{1 観測での確認}

*クラスター効果の議論には, 阻止能でなく局 所的高密度エネルギー付与を議論するほうが本 質的である*

Table 1 に，観測から知られている少数クラスター効 果と理論・計算機シミュレーションによって確認された 事柄とを纒めた。『サイズ効果を無視できない非線形性 がある』ことは初期の害験 ${ }^{16,17)}$ で明らかにされ，顕著な クラスター効果は, 衝突カスケードが前駆過程 ${ }^{1}$ となる スパッタリングの場合に見られた。

その理由を Andersen ${ }^{16)}$ は，『物質中に急激かつ局在し た狭い領域にエネルギーが付与され，短時間内に衝突力 スケード中への局所高密度エネルギー付与が起きた』た めと想像した。これに関連する現象に,「クラスターイ オンによる照射アニーリング」がある。結晶シリコンに ボロンイオンを注入後, 結晶性回復とドーパントの置換 を促進してキャリア濃度を増すためにアニーリングを行 う。このときデカボロン $\mathrm{B}_{12} \mathrm{H}_{14}$ ビームを用いると，単 原子 $\mathrm{B}$ ビームを用いた時に比べてアニーリングの温度 下限が $300 \mathrm{~K}$ も低い ${ }^{18)}$ 。この実験の原因が果たして『ク ラスターイオン特有』かどうか検証する必要がある。

本稿では分子効果とクラスター効果を同じカテゴリー と捉えるため, 敢えて 2 原子分子もクラスターに含め ることにする。 
Table 1. $E_{\mathrm{c}}\left(v_{\mathrm{c}}\right)$ indicates the energy of a cluster $\left(\mathrm{X}_{\mathrm{n}}\right)$ beam impinging target $\mathrm{Z}_{2}$ where atoms cohere with the binding energy $E_{\mathrm{b}}$ and the displacement energy is $E_{\mathrm{d}}$. In the case of $\mathrm{Au}_{\mathrm{n}}{ }^{+} \rightarrow \mathrm{Au}$ target, the maximum $(\mathrm{d} E / \mathrm{dx})_{\mathrm{n}}$ is given by a projectile with energy of $800 \mathrm{keV}\left(=0.4 v_{0}\right)$.

\begin{tabular}{|c|c|c|c|c|}
\hline $\begin{array}{l}\text { Event } \\
(\mathrm{d} E / \mathrm{dx})_{\mathrm{e}} \\
2^{\text {nd }} \text { electron } \\
\text { emission }\end{array}$ & $\begin{array}{l}\text { Collision system }\left(\mathrm{X}_{\mathrm{n}} \rightarrow \mathrm{Z}_{2}\right) \\
\mathrm{H}_{\mathrm{n}} \rightarrow \mathrm{C}, \mathrm{Au}(n \leq 3) \\
\mathrm{H}_{\mathrm{n}} \rightarrow \mathrm{C}(n \leq 19) \\
\mathrm{Z}_{1} \rightarrow \text { metal, graphite } \\
\mathrm{Z}_{1} \rightarrow \mathrm{C}\end{array}$ & $\begin{array}{l}\operatorname{Region}\left(E_{\mathrm{c}}(\mathrm{eV}) / n \text { or } / v_{\mathrm{c}}(\right. \\
60 \leq E_{\mathrm{c}}(\mathrm{keV}) / n \leq 150 \\
30 \leq E_{\mathrm{c}}(\mathrm{keV}) / n \leq 300 \\
(\mathrm{~d} E / \mathrm{dx})_{\mathrm{e}} \text { dominant } \\
0.5 \leq v_{\mathrm{c}} \leq 2.5\end{array}$ & $\begin{array}{l}\left.\left.v_{0}\right)\right) \\
17) \\
30) \\
31) \\
32)\end{array}$ & $\begin{array}{l}\text { Output } \\
R_{\mathrm{n}} \geq 1(\text { distant collision model }) \\
R_{\mathrm{n}} \leq 1, \mathrm{dR}_{\mathrm{n}} / \mathrm{d} E<0, \mathrm{~d} R_{\mathrm{n}} / \mathrm{dn}<0 \\
R_{\mathrm{n}} \leq 1(\text { sweeping-out-model }) \\
R_{\mathrm{n}} \leq 1\end{array}$ \\
\hline $\begin{array}{l}\text { Exciton } \\
\text { luminescence } \\
\text { Radiat. annealing? } \\
\text { Sputtering }\end{array}$ & $\begin{array}{l}\mathrm{Ag}_{\mathrm{n}}^{+} \rightarrow \mathrm{Ar} \text { on metal }(n \leq 3) \\
\mathrm{B}_{10} \rightarrow \mathrm{c}-\mathrm{Si} \\
\mathrm{X}_{2}^{+}(\mathrm{Cl}, \mathrm{Se}, \mathrm{Te} \rightarrow) \mathrm{Si}, \mathrm{Ag}, \mathrm{Au} \\
\mathrm{N}_{2} \text { or } \mathrm{O}_{2} \rightarrow \mathrm{Au} \\
\mathrm{Au}_{\mathrm{n}}^{+} \rightarrow \mathrm{Au}(n \leq 5) \\
\end{array}$ & $\begin{array}{l}500 \mathrm{eV} / \text { atom } \\
200-207 \mathrm{keV} / n \\
v_{\mathrm{c}} \leq 0.038 \\
0.064 \leq v_{\mathrm{c}} \leq 1 \\
\end{array}$ & $\begin{array}{l}\text { 18) } \\
16) \\
33) \\
\text { 21) } \\
\end{array}$ & $\begin{aligned} & \text { Cluster impact } \rightarrow \text { Exciton } \\
& \rightarrow \text { Luminescence } \\
& \text { lower annealing Temp. than } \mathrm{B} \rightarrow \mathrm{Si} \text { Temp } \\
& R_{2}>1 \\
& 1<R_{2} \leq 4 \\
& R_{\mathrm{n}} \sim 100 \mathrm{n}^{2}, Y=Y\left(E_{\mathrm{c}}\right)\left(^{*}\right)\end{aligned}$ \\
\hline $\begin{array}{l}\text { Sputtering } \\
\text { Dissociation } \\
\text { Number-density } \\
\text { Significance of } \\
\text { size or partial energy }\end{array}$ & $\begin{array}{l}\mathrm{Au}_{\mathrm{n}}{ }^{+} \rightarrow \mathrm{Au}(n=5,13) \\
\mathrm{Au}_{\mathrm{n}}{ }^{+} \rightarrow \mathrm{Au}(n \leq 201) \\
\mathrm{C}_{60} \rightarrow \mathrm{C}(111) \\
\mathrm{Al}_{\mathrm{n}} \rightarrow \mathrm{Al}, \mathrm{Au}(n=32 \text { or } 63) \\
\mathrm{Cu}_{\mathrm{n}} \rightarrow \mathrm{Cu}(100)(n=13 \text { or } 92)\end{array}$ & $\begin{array}{l}20 \leq E_{\mathrm{c}}(\mathrm{keV}) / n \leq 1500 \\
0.16 \leq E_{\mathrm{c}}(\mathrm{keV}) / n \leq 64 \\
E_{\mathrm{c}} / n>E_{\mathrm{b}} \\
1 \mathrm{keV} \\
n=92 ; \mathrm{A}\left(E_{0}=E_{\mathrm{b}}\right), \\
\mathrm{D}\left(E_{0} \ll E_{\mathrm{b}}\right) \\
n=13 ; \mathrm{C}\left(E_{0}=E_{\mathrm{b}}\right), \\
\mathrm{B}\left(E_{0}=E_{\mathrm{d}}\right), \\
\text { Same } E_{\mathrm{c}} \text { for A, B } \\
\text { Same } E_{0} \text { for A, C }\end{array}$ & $\begin{array}{l}\text { 11) } \\
\text { 19) } \\
\text { 24) } \\
\text { 20) }\end{array}$ & $\begin{array}{l}Y \propto n^{2} \text { scaling, } Y=Y\left(E_{\mathrm{c}}\right)\left(^{*}\right) \\
Y=Y\left(E_{\mathrm{c}}\right)\left({ }^{*}\right) \\
\mathrm{X}-\mathrm{Z}_{2} \text { comb. } \\
2 \text { times larger density for } 20 \mathrm{fs} \\
\text { Crater formation in B } \\
\text { Deposition in D } \\
\text { Larger damage in A than C } \\
\text { Partial energy }\left(E_{0}\right) \text { is significant }\end{array}$ \\
\hline
\end{tabular}

\section{2 理論・計算機シミュレーションでの確認} * MD は多重衝突に有用な解法の一つである* 高エネルギーイオンの薄膜透過実験は，電子的阻止能 $(-\mathrm{d} E / \mathrm{dx})_{\mathrm{e}}$ へのクラスター効果を直接観察できる。水 素クラスターでは Table 1 に示したように有意なクラス ター効果が観測され，Brandt ら ${ }^{17)}$ はこの結果を『複数の 水素の円筒状の遠隔衝突領域が重なり, あたかも併合点 電荷 (“united point charge”) が存在したような相乗効果 が出た』と考えた。この併合モデルは Table 1 中央部の $\left.{ }^{*}\right)$ で示す，『全エネルギースケーリング』と関係し， MD によって検証もされている ${ }^{11,19)}$ 。

Table 1 の二重線より下がシミュレーション結果であ る。複数原子の同時入射における物質表面の動的相互作 用でも，電荷交換や励起原子の脱励起 ${ }^{6)}$ などが起こらな い場合には古典的 MD でも解析できる。

Shapiro と Tombrello ${ }^{20)}$ は 1990 年 $\mathrm{Au}_{n}{ }^{+}$を $\mathrm{Au}$ 標的に照 射した場合について MD を適用し，照射効果における 単原子ビームとの違いを初めて明らかにした。個別エネ ルギー $E_{0}=1 \mathrm{keV} /$ atom $\left(v=0.014 v_{0}\right)$ は Andersen ${ }^{21)}$ が実 験に用いたエネルギーよりも更に低いが，それでも物質 中の衝突カスケード領域では $20 \mathrm{fs}$ の間，原子密度が通 常の約二倍になる圧縮状態を確認した。この数值はクラ スター衝撃による圧力上昇を検証した一つのランドマー クである。

半年遅れて Averback ら ${ }^{22)}$ は MD を用い, $E_{0}\left(=E_{\mathrm{C}} / n\right)$ の
大きさによってイオン衝撃の結果を分類した。Table 1 のように同じ $E_{\mathrm{C}}(\mathrm{A}$ と B $)$ と同じ $E_{0}(\mathrm{~A}$ と $\mathrm{C})$ を比較 した。 $E_{0}$ が固体の吒出しエネルギー $\left(E_{\mathrm{d}}\right)$ 相当ならば クレーター形成，凝集エネルギー $\left(E_{\mathrm{b}}\right)$ 相当ならば，表 面近傍で固体原子と化合, それより小さければ表面堆積 した。同じ $E_{0}$ ならば起った現象の強度は $\mathrm{X}_{\mathrm{n}}{ }^{+}$のサイズ $n$ に応じて増大する。ちなみにクレーター形成は, 単原 子イオン衝撃でも可能である ${ }^{23)}$ 。

その 4 年後, Galli と Mauri ${ }^{24)}$ は，QMDを用いて， $E_{0}$ と $E_{\mathrm{b}}$ との相関を再確認した。 $\mathrm{C}_{60}$ ビームがダイヤモン ド（C (111)）表面を衝撃する場合に, HellmannFeynman 則に従って決めた原子間力を MD に組み入れ た。 $E_{0}$ が $E_{\mathrm{b}}$ より小さいときクラスターは固体原子と結 合することなく固体表面から緩く跳ね返される。しかし $E_{0}$ が $E_{\mathrm{b}}$ を超えるとフラーレンは解離し, 原子は表面原 子との間に安定な結合を作った。彼らは量子力学計算の 重要性を述べたが，実際に実験例 ${ }^{6}$ のような低エネルギ ービームによる発光過程もあり, 低エネルギーでも励起 電子と局在フォノンの相互作用の記述が重要な問題に関 しては, 非平衡 $\mathrm{QMD}^{25}$ か時間依存密度汎関数法（Timedependent density functional theory, TDDFT $\left.{ }^{26)}\right)$ かが必要で ある。外にもクラスターイオンによって顕著に示される イオントラック形成 ${ }^{27)}$ な゙はあるが，単原子イオンによ っても形成される ${ }^{28)}$ 場合は Table 1 から割愛した。

計算機シミュレーションでは，固体に入射するクラス 
ターイオン $\left(\mathrm{X}_{\mathrm{n}}\right)$ のイメージを, エネルギーの増加に

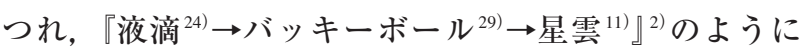
描くことがある。この変化は, X と固体原子との衝突断 面積と $X-X$ 間の結合ボンドとが, 共にこの方向に相対 的に弱まることから来る。計算はクラスターの幾何構造 特定から始まるが, 実験的に検証できる場合は限られる ${ }^{2)} 。$

系のサイズが約 $10 \mathrm{~nm}$ 以下の空間では量子効果 ${ }^{35)}$ が避 けられず電子状態が重要である。本稿でいう巨大クラス ターもほとんどがその範囲に含まれ ${ }^{36)}$, 可能な幾何構造 の候補から安定構造を決定するには, 基本的には第一原 理的分子軌道法 ( $a b$ initio molecular orbital method, $\mathrm{QMO})^{37)}$ によって, 触媒金属元素の有無 ${ }^{38)}$, 価数 ${ }^{39)}$, 溶 媒の有無 ${ }^{38)}$ ，などを反映して決まる。

$\mathrm{QMO} に よ っ て 『 n$ 個の $\mathrm{X}$ 原子からつくる $\mathrm{X}_{\mathrm{n}}$ の幾何 構造を選定するには，原子集団のあらゆる可能な集合状 態を $\left\{\mathrm{X}_{\mathrm{i}}-\mathrm{X}_{\mathrm{j}}\right\}$ 間の相対的な位置関係（=多自由度の配 位座標の 1 セット）で表現し，1 セットごとに一つの全 エネルギー值を計算する。この結果，任意の集合状態に 対する基底状態のエネルギー值の集合は，一枚のエネル ギー曲面 (potential energy surface, PES) となる ${ }^{34)} 。$

Fig. 1 は典型的な 2 次元 PES の等高線表示である。記 号 $\mathrm{M}$ は極大值, $\mathrm{m}$ は極小值, $\mathrm{s}$ は鞍点を示し, 実線は 個々の極小值の持つエリアの境界線を示す。この極小值 は一般に複数あり「最も深い極小值を, 最も確からしい クラスターの静的安定構造」と判定する。

本来的には, $n$ 個の原子には $3 n$ 個の自由度があるの で, PES は Fig. 1 のような 2 次元ではなく $3 n$ 次元の関 数になるはずである。しかし反応に関与するのは結合の 弱い部位で，しかもクラスター内部の原子間には独特な 相互連携があって部分的にせよ何らかの対称性を保ちつ つ微動する。したがって, 課題ごとに最も反応の起こり やすそうな変化の部位を選択し, 真に有意な変換座標だ

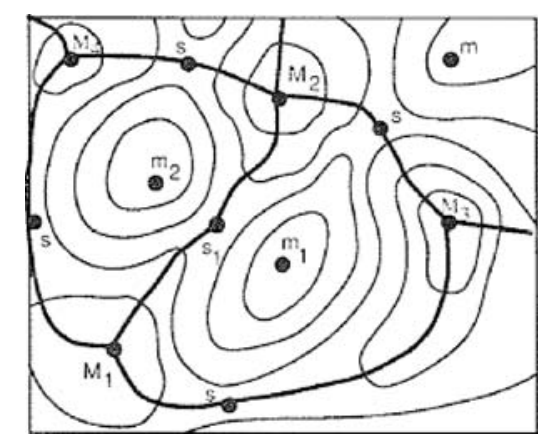

Fig. 1. A contour map of a typical PES presented as Fig. V. 7 in ref. [34]. Solid lines connect maximum points (M) via a saddle point (s), which segment into catchment regions enclosing one potential minimum (m).
けに絞り込む理論的直観は可能である ${ }^{34)}$ 。Fig. 1 は整理 し尽くされた二つの配位座標による 2 次元 PES の模式 図である。絞り込みの極限には, Frank-Condon 原理に 基づいて固体中の局在電子の励起状態を議論する配位座 標（基底状態 $\mathrm{A}_{1 \mathrm{~g}}$ ）がある。それは電子の属する原子を 中心に, 最隣接原子集団が同位相で連動する脈動的な単 一の振動モードを意味する。

Fig. 1 で表す PES の面上の各点が表すのは系の静止状 態での基底状態である。その上方のエネルギー空間には 多数の振動準位と回転準位が層状に詰まっていて, 内外 からの擾乱があれば振動準位を介して遷移が起こる。そ れを Fig. 1のような射影図を用いると，『原系i（極小点

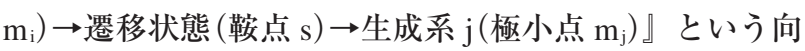
きに鞍点 $\mathrm{s}$ の峠を乗り越えて進む反応経路と表現して, クラスターの変形や解離を含めて幾何構造が変わる仕組 みを説明する。クラスタービームと物質表面の動的な相 互作用の予測のためにも一連の理論計算は重要である。

PES が単なる概念図でもない実例として, 分子量 $7 \times 10^{4} \mathrm{u}$ の巨大クラスターである熱ショック蛋白質 Hsc70 の主要部をなすATP から, 加水分解によって ADP が作られる過程を検証するための 2 次元 PES 計算 を Fig. 2 に示す ${ }^{40)}$ 。この際の絞り込まれた二つの座標は ATP に対する水分子の位置である。 35 個の原子からな る原系（a）が，遷移状態（b）をへて，より安定な生成 系（c）に移行する様子を捉えている。

\section{3 少数クラスターのスケーリング}

*サイズ効果は不分離か? *

$E_{0}$ をスケーリングに用いた理由は二つあった。

1）『阻止能』は良く整理された概念で，そこで用いら

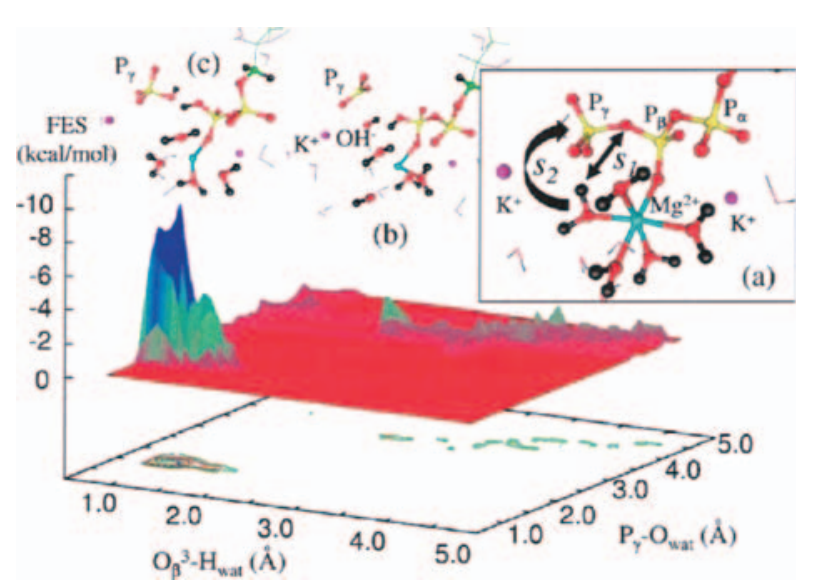

Fig. 2. (color online). A two-dimensional PES showing a reaction of $\mathrm{Hsc70}(70 \mathrm{ku})$ production during the course of APT $\rightarrow$ ADP by means of hydrolysis, from Fig. 5 in ref. [40], with kind permission of Springer Science + Business Media. 
れた速度の方が, クラスターサイズよりも, 固体内原子 衝突と言う観点からは本質的である,

2）等価速度で単原子との比較をすれば，非線形性を 定量できる。低エネルギーで行われた $\mathrm{MD}^{22,24}$ が，その 優位さを確認した。

ところが Table 1 中に二重線を挟んで $\left(^{*}\right)$ の記号で示 した事例は，比較的エネルギーが高く重い原子が関わる 場合のスパッタリングに見られる，全エネルギー $E_{\mathrm{C}} に$ よるスケーリングの事実である ${ }^{2)}$ 。 $E_{\mathrm{C}} / n$ による類別は阻 止能の考えに基づくものであり, クラスター効果を $R_{\mathrm{n}}=Y\left(\mathrm{X}_{\mathrm{n}}\right) / n / Y(\mathrm{X})$ と考えることは, 阻止能が加算的と いう想定に基づいている。しかし阻止能が決めているの は単位長さ当たりのエネルギー付与で, その空間横広が りの情報はない。放射線被ばくの線量等量の議論では, 狭い空間に高密度エネルギー付与をする $\alpha$ 線と希薄な 効果をもたらす X 線とでは線質係数に 20 倍の差が考虑 されている。 $R_{\mathrm{n}}$ においてもエネルギーの体積密度の違 いは重要である。

\section{3. 低速巨大クラスタービームと物質の相互作 用の特異性 \\ *固体内原子衝突モデルからの脱却*}

少数粒子系のクラスタービームの特異性はクラスター工 学への関心を高め ${ }^{41)}$, 用いるクラスターサイズの幅も徐々 に大きくなった。グリセリンクラスター(質量数 $10^{9} \mathrm{u}$, 価数〜200）が効率良く表面近傍のタンパク分子（質量 数 $3 \times 10^{5} \mathrm{u}$ ) を分解しないで効率的に脱離させる ${ }^{42)}$ と いう, クラスターSIMS の技術も発展し, 生化学的応用 面からの期待も高い ${ }^{43)}$ 。

現在利用が進んでいる巨大低速クラスターイオンは, 印加電圧が数 $\mathrm{keV}$, 構成原子数が数万個 $\left(\sim 10^{6} \mathrm{u} / \mathrm{e}^{-}\right)$, 系の直径は（～数 $\mathrm{nm} ）$ であるので, 1 原子あたりでは 音速程度までスピードが下がっている。3.2で述べる新 規な現象からして, 巨大クラスターと固体との相互作用 の理論解析には, 少数クラスターとは若干異なったモデ リングの発想が期待されている。

\section{1 巨大クラスターの形状と電子状態}

\section{*巨大クラスターはミクロなバルクである*}

巨大クラスターは有極性の強い分子が構造単位となる ことが多く, 単原子クラスターの安定構成原子数として 知られるマジック数が, 解離片の選択的放出サイズとし て現れることもある(4)。

クラスターの構成原子数を増やしていくと, 原子間距 離, 結晶構造, イオン化ポテンシャルなどは, およそ 10 個を超えるあたりから既にバルク化の傾向を見せ, 数密度も凝集系の值にほほ近くなる ${ }^{38,39)}$ 。PES 上方の電
子エネルギー準位は密集し, バルク結晶に見られる Jahn-Teller 効果のように『周辺の原子配位や熱振動を反 映した振電状態』の準位群ができる。しかし電子状態の バンド的構造形成にはまだ遠い。

系のサイズが $10 \mathrm{~nm}$ 以下では量子効果 ${ }^{35}$ )が現れ, 特に ダングリングボンドの納まり方が, クラスター全体の幾 何構造を大きく支配する。実際, 全構成原子数に比べた 表面原子数の割合は, 1000 個のクラスターでも約 4 割 に達するので QMD が必要である。クラスターサイズが 大きくなる時, 先に述べた PES を QMO で計算すると きは，密度汎関数法を用いるが，巨大化するにつれ害際 上それも不可能になる。したがって, Fig. 2のような反 応部位の切り出しという飛躍モデルが不可能な場合, 数 值計算の容量からは現実的には原子間ポテンシャルを構 成要素に用いて, 古典的 MD 法でアニーリングによっ て準安定状態を探し, 決めざるを得ない ${ }^{36)}$ 。電子構造の 異方性を無視して MD を行うと, 一般的には球状クラ スターが一つの準安定状態になるが, 共有結合 ${ }^{45}$ や水素 結合が明らかな場合は, 若干の改善が MD にも可能で ある。

巨大クラスターの衝撃による物質の影響を評価するに は, 物質中に渗入する所要時間や表面との接触面積の評 価が重要である。したがって, サイズ効果の見積もり が, 粒子（分子）の個数 $n$ ではなくて, $n^{1 / 3}$ (球状 $\mathrm{X}_{\mathrm{n}}{ }^{+}$ の径) や $n^{2 / 3}$ (断面積) のほうが実際的である。すなわ ち数個の原子集団ではなく, 如何に『ミクロなバルク』 に近いかの方にサイズ効果の関心は移った ${ }^{38)}$ 。

\section{2 巨大クラスターと物質との長距離相互作用 *粗視化した QMD が必要*}

こうして得られた巨大クラスター内部の原子（分子） 間結合は $E_{\mathrm{b}} \sim$ 数 $\mathrm{eV}$, 標的内部のそれは $E_{\mathrm{d}} \sim$ 数〜数十 $\mathrm{eV}$, 巨大クラスター間の結合はその $1 / 10$, 固体表面に 物理吸着した分子の結合エネルギーはさらにその $1 / 10$ 程度である ${ }^{46)}$ 。この析渡りの数值の違いが, クラスター 間の分離を可能にする一因である。さらに表面に吸着し た巨大分子の剥離の際, 固体との接触界面の内側にあっ て長距離相互作用で結ばれているミニバルク領域の粒子 の内的結合は剥離の影響を受けないため, 剥離には界面 原子の結合切断でこと足り, 少数クラスターの剥離より 相対的に小さい仕事で足りる。これによってクラスター SIMS が可能となる。

本稿で問題にする巨大クラスターと，それに対する物 質の双方を組み入れた計算機シミュレーションを, 原子 分子の観点を失わずに行うのはサイズ的に困難なので, ここでは物質表面での衝突によって衝突励起をうけるク ラスター側の力学的扔よび電子的効果 (Clusterelectric 
effect）を考える。

（イ）压縮領域：巨大クラスターが固体表面に当ると き，表面での反跳を受けることによって一部の分子が重 心の運動とは逆向きの運動量を受け, 内部に分子の高密 度領域ができる可能性がある。もしクラスターの体積が 局部高密度領域に対して大きいならば，クラスター内部 には数原子層にわたる密度の急上昇した, 局所高密度フ ロントの発生する可能性がある ${ }^{47) 。 ~}$

（ロ）マイクロバブルの発生：高速水クラスターには クラスター中に衝撃によって気泡が生じることがある。 この場合，気相が圧力緩和を担うために極限状態の緩和 が通常 $100 \mathrm{fs}$ のところ $100 \mathrm{ps}$ にも延長する ${ }^{48)}$ 。逆にみ ると, クラスターの解離は緩衝機構がないための直結的 なエネルギー掃出しといえる。

（八）衝突解離：衝突励起エネルギーがクラスター内 の分子の回転準位や振動準位に対して小さいならば，ク ラスターは単量体を吐き出して安定化する ${ }^{49)}$ 。クラスタ 一内の粒子間結合が切れるとき, 結合の弱い分極性のも のから切れる筈だからである。衝突励起エネルギーが大 きいと, クラスターは複数の解離片かマイクロプラズマ のような霧状片となる。

（二）電子正孔対：クラスターに光子が入射したとす ると, 電離によって局在エキシトンのような電子正孔対 (geminate charge pair ${ }^{50}$ が生成する。これは『相互遮蔽 (mutual shielding)』によってクラスター全体が中性であ ることには影響を与えず観測も難しい。クラスターの解 離で正負の解離片が観測される場合, 偶然に別のセグメ ントに乗っていた電荷対が解離の際に分離したとして, 成因を説明できる。

（ホ）構造相転移：内部温度の変化をトリガーに電子 状態が変化し, 全体的な構造相転移が引き起こされ

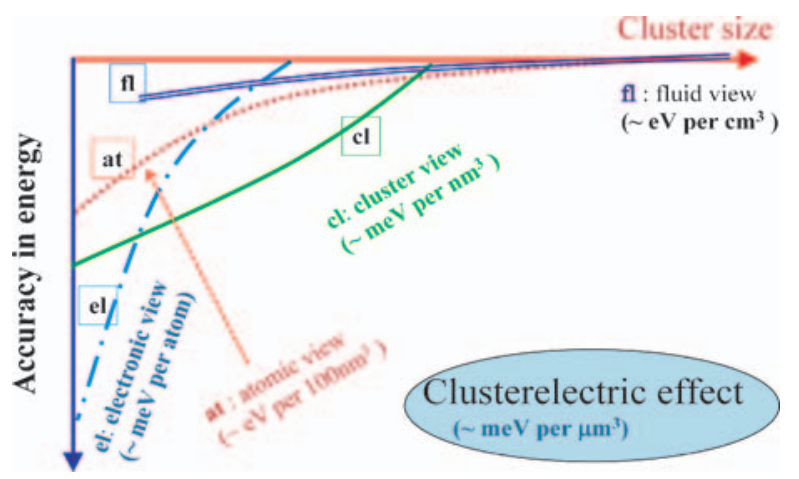

Fig. 3. (color online). The possibility and restriction for each algorism in the present numerical calculations. The hatched zone is the specific region that is required for the Clusterelectric effect.
る ${ }^{51}$ 。（イ）や（口）はMD に水力学を考慮して大規模 計算の可能性がある。しかし（ハ）～（ホ）は電子状態 のダイナミックスが重要で QMD が必須である。

Fig. 3 は 4 種類の立場 (electronic, cluster, atomic, fluid) view について，カバーできる空間拡がり $(\Delta V)$ と，期 待できるエネルギー值の精度 $(\Delta E)$ を区分する。一点 鎖線の electronic view（el）は第一原理計算 (CoupledChannel, MO, QMD）を用いて全電子に付いて $\Delta E<\mathrm{meV}$ を目指す。実線の cluster view（el）も同様の精度 $\Delta E \sim \mathrm{meV}$ を, しかし外殼電子に付いて $\Delta V \sim(4 \mathrm{~nm})^{3}$ の領域で求める。両者は共に非等方的な電荷分布を考慮 するが，破線の atomic view（at）では等方分布した電子 の寄与を原子間相互作用に繰り込み, $(\mathrm{MC}, \mathrm{MD}, \mathrm{KMC})$, $\Delta V \sim(0.25 \mu \mathrm{m})^{3}$ の領域で原子に付き $\Delta E \sim \mathrm{eV}$ を目指 す。一方，入射粒子と相互作用する固体を粒子猫像でな く水力学的な連続媒質と見る二重線 fluid view（fl）は, $\Delta V \sim \mathrm{cm}^{3}$ の領域で $\Delta E \sim \mathrm{eV}$ を目指す。従来の手法は, 期待できる計算精度と扱える系のサイズとの間に負の相 関がある点で共通している。しかし巨大クラスターにお ける電子状態の理解の目的は Fig. 3 の右下の楕円で囲ん だ clusterelectric effectにあり, 実線から二重線につな ぎ, $\Delta V \sim \mathrm{mm}^{3}$ の領域でなおかつ外殼電子につき $\Delta E \sim m e V$ を要求するが, これは従来手法の限界を越える。

この限界をクリアする方策の一つは，空間粗視化によ る限界の先延ばしである ${ }^{52)}$ 。セグメントと呼ぶ有限体積 の個々について，情報を平均化（一元化）して一つの情 報単位として，その変化を追っていくという繰り込みで ある。

電子状態の変化を含む粗視化は容易ではないが，既存 の非平衡 $\mathrm{QMD}^{33}$ か $\mathrm{TDDFT}^{34}$ を元に空間粗視化し，しか も構造相転移のトリガーを消さないような工夫を容れる 必要がある。このような粗視化した第一原理的 QMD の アルゴリズムを，クラスター衝撃の課題に適用できるよ うな方向で発展させることが早急に期待される。

\section{4. ま と め}

少数クラスターと物質の相互作用について等価速度ス ケーリングが必ずしも成立せず，全エネルギースケール が存在する場合もあることを指摘した。これは，クラス ターの場合, エネルギー付与密度の考慮が重要なことを 意味する。量子効果が重要なクラスターの電子状態につ いては, 物質との相互作用についても第一原理計算分子 動力学が必要であるが, 特に巨大クラスターについては 計算サイズの限界から実行には無理がある。低速の巨大 クラスターについては空間粗視化が必要であり, 今後, 粗視化した第一原理分子動力学の活用が期待される。 


\section{文献}

1) P. Sigmund : "Particle Penetration and Radiation Effects" (Springer-Verlag, Berlin, Heidelberg, 2006).

2) S.T. Nakagawa: J. Surf. Sci. Soc. Jpn. 52, 224 (2009).

3) J. Lindhard, M. Scharff and H.E. Schiǿtt: K. Dan. Vidansk. Selsk. Mat-Fys. Medd. 33, no. 14 (1963).

4) http://www.srim.org/

5) P. Sigmund : Europ. Phys. J.D 47, 45 (2008).

6) W. Harbich, C. Sieber, K.-H. Meiwes-Broer and C. Felix : Phys. Rev. B 76, 104306 (2007).

7) J.B. Gibson, A.N. Goland, M. Milgram and G.H. Vineyard : Phys. Rev. 120, 1229 (1960).

8) D.G. Pettifor: "From Exact to Approximate Theory: The Tight Binding Bond Model and Many-body Potentials", ed. by R.M. Nieminen et al. (Springer-Verlag, Berlin, 1990) pp. 64-84.

9) A. Caro and M. Victoria : Phys. Rev. A 40, 2287 (1989).

10) L.A. Marqués, L. Pelaz and I. Santos : Phys. Rev. B 74, 201201 (R) (2006).

11) J. Samela and K. Nordlund : Phys. Rev. B 76, 125434 (2007).

12) S.T. Nakagawa: "Semiconductors and Semimetals" 45 (Academic Press, Boston, 1997) Chap. 3.

13) D.R. Cox and H.D. Miller: "The Theory of Stochastic Processes" (Methuen, London, 1965) pp. 6-7.

14) R. Car and M. Parrinello: Phys. Rev. Lett. 55, 2471 (1985).

15) E.W. Becker, K. Bier and W. Henkes : Z. Phys. 146, 333 (1956).

16) H.H. Andersen and H.L. Bay: J. Appl. Phys. 45, 953 (1974)

17) W. Brandt, A. Ratkowski and R.H. Ritchie : Phys. Rev. Lett. 33, 1325 (1974).

18) N. Hamamoto, S. Umisedo, T. Nagayama, M. Tanjyo, S. Sakai, N. Nagai, T. Aoyama and Y. Nara : Nucl. Instrum. Methods Phys. Res. B 237, 443 (2005).

19) S. Zimmermann and H.M. Urbassek : Nucl. Instrum. Methods Phys. Res. B 255, 208 (2007).

20) M.H. Shapiro and T.A. Tombrello : Phys. Rev. Lett. 65, 92 (1990).

21) H.H. Andersen, A. Brunelle, S. Della-Negra, J. Depauw, D. Jacquet, Y. Le Beyec, J. Chaumont and H. Bernas : Phys. Rev. Lett. 80, 5433 (1998).

22) H. Hsieh and R.S. Averback: Phys. Rev. B 42, 5365 (1990).

23) K.L. Merkle and W. Jäger : Phil. Mag. 44, 741 (1981).

24) G. Galli and F. Mauri : Phys. Rev. Lett. 73, 3471 (1994).

25) U. Saalmann and R. Schmidt : Phys. Rev. Lett. 15, 3213 (1998).

26) O. Sugino and Y. Miyamoto: Phys. Rev. B 59, 2578 (1999).

27) S.M.M. Ramos, N. Bonardi, B. Canut and S. DellaNegra : Phys. Rev. B 57, 189 (1998).
28) G. Bonfiglioli, A. Ferro and A. Mojoni : J. Appl. Phys. 32, 2499 (1961).

29) P. Blaudeck, T. Frauenheim, H.-G. Busman and T. Lill : Phys. Rev. B 49,11409 (1994).

30) N.V. de Castro Faria, B. Farizon Mazuy, M. Farizon, M.J. Gaillard, G. Jalbert, S. Ouaskit, A. Clouvas and A. Katsanos : Phys. Rev. A 46, R 3594 (1992).

31) A.M. Borisov, E.S. Mashkova and E.S. Parilis : Vacuum 66, 145 (2002)

32) N.R. Arista, M.M. Jakas, G.H. Lantschner and J.C. Eckardt : Phys. Rev. A 34, 5112 (1986).

33) Y. Yao, Z. Hargitai, M. Albert, R.G. Albridge, A.V. Barnes, J.M. Gilligan, B. Pratt Ferguson, G. Lüpke, V.D. Gordon, N.H. Tolk, J.C. Tully, G. Betz and W. Husinsky : Phys. Rev. Lett. 81, 550 (1998).

34) P.G. Mezey : "Potential Energy Hypersurfaces" (Elsevier, Amsterdam, 1987) Chapter V. 2.

35) R. Kubo : J. Phys. Soc. Jpn. 12, 570 (1957).

36) A. Heidenreich, J. Jortner and I. Last : PNAS 103, 10589 (2006).

37) R. Dronskowski : "Computational Chemistry of Solid State Materials” (Wiley-VCH Verlag GmbH \& CXo. KGaA, Darmstadt, 2005).

38) A.W. Castleman and P. Jena : PNAS 103, 10554 (2006).

39) S.T. Nakagawa, I. Suzue, M. Itoh, M. Kageyama, Y. Mizuno and H.J. Whitlow : J. Nucl. Mater. 363-365, 1289 (2007).

40) M. Boero : in "Atomic-scale Modeling of Nanosystems and Nanostructured Materials”, ed. by C. Masobrio, H. Bulou and C. Goyhenex (Springer, Heidelberg, 2009) Chapter 3.

41) H. Haberland, M. Karrais, M. Mall and Y. Thumer: J. Vac. Sci. Technol. A 10, 3266 (1992).

42) D. Fabris, Z. Wu and C.C. Fenselau : J. Mass Spectrom. 30, 140 (1995).

43) P-Y. Cheng, J, S. Baskin and A.H. Zewail : PNAS 103, 10570 (2006).

44) P. Jena and A.W. Castleman : PNAS 103, 10560 (2006).

45) S. Maruyama and Y. Shibuta: Mol. Cryst. Liq. Cryst. 387, 87 (2002).

46) C.E. Klots : Z. Phys. D 5, 83 (1987).

47) I. Schek and J. Jortner : J. Chem. Phys. 104, 4337 (1996).

48) B. Gompf, R. Günther, G. Nick, R. Pecha and W. Eisenmenger : Phys. Rev. Lett. 79, 1405 (1997).

49) F. Gobet, B. Farizon, M. Farizon, M.J. Gaillard, S. Louc, N. Gonçalves, M. Barbatti, H. Luna, G. Jalbert, N.V. de Castro Faria, M.C. Bacchus-Montabonel, J.P. Buchet, M. Carré and T.D. Märk : Phys. Rev. Lett. 86, 4263 (2001).

50) C.R. Gebhardt, H. Schröder and K.L. Kompa : Nature 400, 544 (1999).

51) Y. Matsumoto and K. Honma: Chem. Phys. Lett. 490, 9 (2010).

52) 中川幸子: 電気学会 論文誌 C (特集 [量子ビームに よるナノバイオ科学と基盤技術]). C 129, 238 (2009). 